\title{
AIR-TEMPERATURE SINGULARITIES AND DIFFERENCES BETWEEN INTRA- AND EXTRA-URBAN WEATHER STATIONS. CASE STUDY: BUCHAREST-FILARET AND BUCHAREST-BĂNEASA
}

\author{
IONAC Nicoleta ${ }^{1}$, URIŢESCU Bogdan ${ }^{1}$, GRIGORE Elena ${ }^{1}$, \\ CONSTANTIN Dana Maria ${ }^{1}$ DUMITRESCU Alexandru ${ }^{2}$
}

Key words: air-temperature, urban spaces, artificial heating, thermal superiority.

\begin{abstract}
It is already a well-known fact that air-temperature is the most important climatic factor of differentiation between intra- and extra-urban areas, mainly due to the characteristics of the underlying active surface. Bucharest townarea is no exception to the rule. Ranking as Romania's largest city, its airtemperature singularities and differences account for the most important example expressing the role that the artificial ground layer may play in the creation of specific urban climates. The thermal differences as well as singularities between the Bucharest town-area (Bucharest-Filaret) and its surroundings (BucharestBăneasa) are analyzed by means of multiple air-temperature parameters: hourly measurements (01, 07, 13 and $19 \mathrm{hrs}$.), daily, monthly, yearly values of maximum, average and minimum means, over a 30 year period (1981-2010). Besides, the analysis of some air-temperature singularities or records highlight the clear differences of air heating processes, mostly due to the different interaction patterns between solar radiation and the underlying active layer, at local scales. However, in general, although the intra-urban areas should keep warmer in summer and cooler in winter, the cooling effects seem to still remain lower in the city because of the greater artificial heat input that is being added to the built-in environment.
\end{abstract}

\section{INTRODUCTION}

Urbanization, which mainly resulted in an intensive spatial concentration of population, dense built-in areas with impervious pavements, multiplied and vertically-differentiated layers of active surfaces, as well as scarcer green infrastructures, is obviously exacerbating any urban climate environment, by

\footnotetext{
${ }^{1}$ University of Bucharest- Faculty of Geography, Bucharest, Romania ionac.nicoleta@geo.unibuc.ro,bogdan_uri@yahoo.com, ela_zigzag@hotmail.com, danamartines@yahoo.com

${ }^{2}$ National Administration of Meteorology, Bucharest, Romania: alexandru.dumitrescu@gmail.com
} 
largely altering the proportion between the urban heat island (UHI) effect, specific of the urban artificial landscapes, and the urban cool island (UCI) effect, characteristic of the green, vegetated spaces and bodies of water sparsely distributed inside the city area or in its surroundings (Chen A. et al., 2014). In this respect, most recent studies have shown that the urbanization effect accounts for a large proportion of the overall annual mean surface air-temperature (SAT) increase at intra-urban meteorological stations, as well as for some significant changing trends of local and regional annual mean SAT values (Bian Tao et al., 2014), consequently enhancing the UHI effect that may disturb the frequency and intensity of extreme temperature events, mostly addressing to the increase of both maximum (Tmax) and minimum (Tmin) air-temperature values over highly variable patch - patterns, as result of different interactions between the radiation processes and the properties of the underlying active surface. In many studies of urban landscape ecology and designing, land surface temperature (LST) is considered as main climatic tool to reflect the potential and ability of a surface area to radiate and conduct heat transport to the atmosphere, as direct result of the solar heating, upward thermal radiation and convective heat loss processes. Besides, LST, abundantly available from remote sensing products, provides a much higher spatial coverage (Voogt and Oke, 2003; Weng, 2009), being easier to be differentiated at smaller scales (sometimes even at patch levels), depending on the composition and configuration of active surfaces. However, relatively few studies have discussed the overall effect of urbanized areas on their surrounding air-environment, as expressed by their compact UHI effect, based on airtemperature values provided by ground-level meteorological stations, partly because relevant comparative intra- and extra-urban stations were either not available or they did not provide reliable data series under relatively characteristic metadata conditions. After all, the process of urban climatization is not necessarily important at the patch-pattern level of urban spaces, depending on the shape (Sun et al., 2012), composition (Li et al., 2011) and configuration (Zhou et al., 2012) of underlying surfaces, but rather at a more general landscape level, where the mean radiant temperature (Tmrt), an important indicator of human comfort and well-being, is directly dependent on the environmental radiative flux (Matzarakis et al., 2010) of urban spaces.

There is no doubt nowadays that latest rapid urbanization process has substantially altered local climate records (Wang et al., 2013), although the results obtained by many studies do not seem to converge to a unitary method on how to best quantify its influence on mean, extreme and long-term local temperatures (Gaffin et al., 2008) and on which indices of extremes might be most reliable and relevant. That is why, when assessing the so-called "urbanization-related signals in temperature records" (Wang et al., 2013), one must always take into consideration 
that long-term time series of observations from intra- and extra-urban meteorological stations might not be homogenous because the observing sites, the instruments and the measurement protocols have greatly changed over time, or the method of classifying the stations in the two main categories (intra- and extraurban) may not always be unanimously applied. Nevertheless, the infra-red energetic input from artificial urban surfaces, traffic and indoor heating leads to some important changes in temperatures inside town areas, so that the concept of UHI has been introduced to denote the thermal difference between the urban builtin spaces and the surrounding open-space environments of cities (Cheval \&Dumitrescu, 2014). For this reason, air-temperatures measured at intra-urban stations are usually higher than those obtained from surrounding rural stations in any season, but they become more obvious during summer, when the additional heat radiated by buildings amplifies the natural warming process of air inside town-areas. In this respect, the present paper discusses the impact of the urban underlying surface on the time range and distribution of air-temperatures in Bucharest town area, based on the comparative values recorded at two different (intra- and extra-urban) meteorological stations, assessing both the intensity and the time gap of the heating and/or cooling processes inside the city.

\section{DATA AND METHODS}

The basic data used in this paper include hourly, daily, monthly and yearly mean, maximum and minimum air-temperature values measured at two representative meteorological stations: Bucharest-Filaret and Bucharest-Băneasa, between 1 January 1981 and 31 December 2010. These data were collected from Romania's National Administration of Meteorology and have included the leap years (with 29 days in February) for more accurate results.

The two weather stations on service in Bucharest town-area are (Fig. 1) : Bucharest-Filaret(located in the centre of the city, at an $82 \mathrm{~m}$-high altitude, $44^{0}$ 24' 49' 'N latitude and $26^{\circ} 05^{\prime} 48^{\prime \prime}$ E longitude) and Bucharest-Băneasa (located at the northern periphery of the town, at an 90 m-high altitude, $44^{\circ} 30^{\prime} 38^{\prime \prime} \mathrm{N}$ latitude and $26^{\circ} 04^{\prime} 41^{\prime \prime}$ E longitude).

Bucharest municipality is lying in the southern part of the country, in the Vlăsia division of the Romanian Plain, at a distance of about $60 \mathrm{~km}$ far off the Danube River, $100 \mathrm{~km}$ off the Carpathian Mts. and $250 \mathrm{~km}$ off the Black Sea shore. The altitudes of the specific nearly level landforms within the city range from $54 \mathrm{~m}$ (Dâmboviţa valley) to $95 \mathrm{~m}$ (in the north-lying Străuleşti district); the mean altitudes averaging $80 \mathrm{~m}$-high in most of the town area, which is administratively divided into 6 sectors, extending from the centre to the periphery of the town, that is traversed by the canalized Dâmboviţa river (flowing on a $266 \mathrm{~km}$-long distance right through the historical centre of the town) and the Colentina river (peripherally flowing across the 
city on a NW-SE direction along $80 \mathrm{~km}$, through 6 regulator lakes which are mainly used for recreational activities). The original wooded-steppe vegetation of the Vlăsia plain is still being preserved only in some north-lying scarce areas that, at present, are used as main recreational places due to their more cooling effects, especially in summer. Unlike these green spots, the built-in area of the city (totalling $238 \mathrm{~km}^{2}$ ) creates specific climatic conditions which could roughly be characterised as highly artificial, since almost all meteorological elements show visible differences between the values recorded at the two urban weather stations.

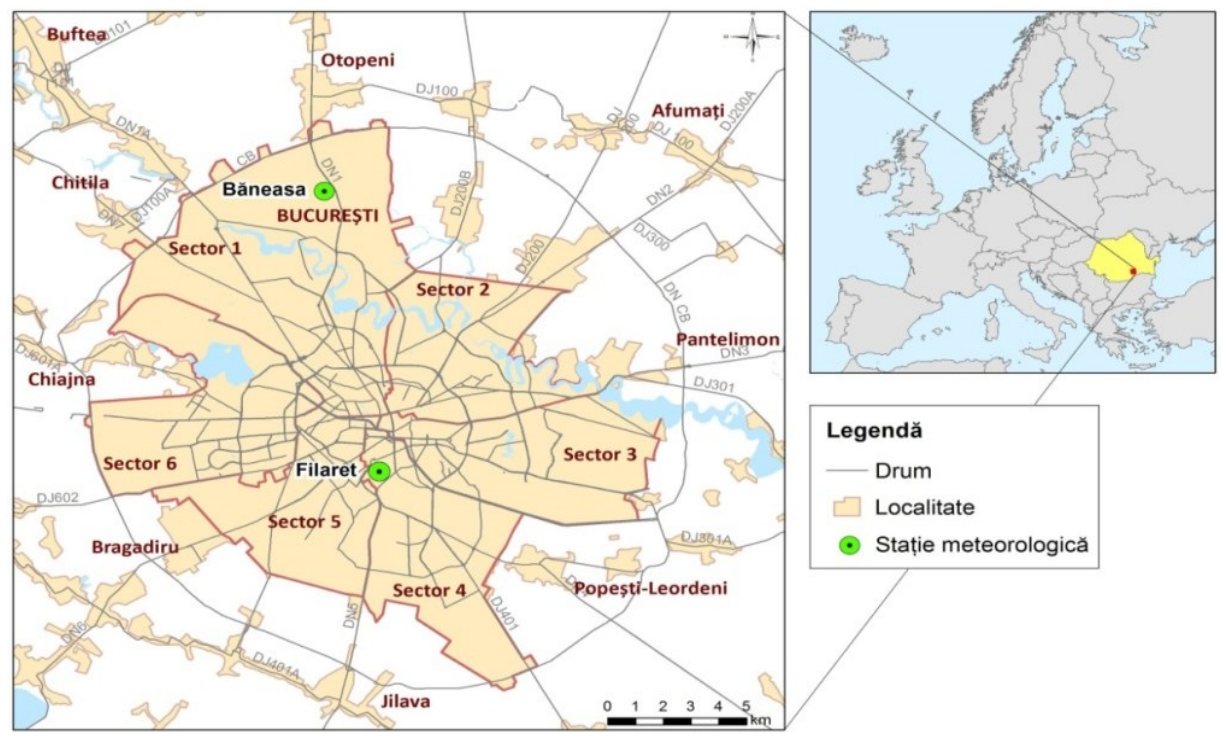

Fig. 1 - Location of weather stations on the territory of Bucharest town-area

The mathematical position of the centre of the town is given by the intersection of the $44^{\circ} 25^{\prime} 50^{\prime \prime} \mathrm{N}$ latitude and $26^{\circ} 4^{\prime} 50^{\prime}$ ' $\mathrm{E}$ longitude lines, meaning that its specific mid-latitude climate of transition may getsome continental influences, characterized by higher mean daily and yearly airtemperature ranges $\left(25-26^{\circ} \mathrm{C}\right)$, lower rainfall amounts more unevenly distributed in time, a higher frequency of droughts in summer and blizzards in winter, as revealed by the corresponding Péguy climograms, in which most months of the year are climatically moderate, falling inside the triangle area separating the three major climate types (cold and wet; hot and dry; arid), except for the winter months (January and February), with negative air-temperatures and low rainfall amounts, and the peak hot and dry summer month (July). 


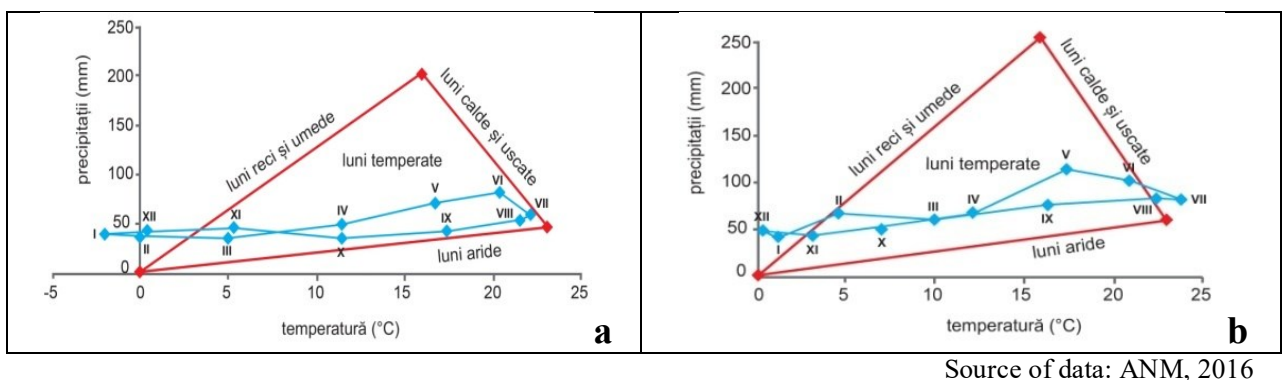

Fig. 2.Péguy climograms for Bucharest-Băneasa (a) and Bucharest-Filaret(b) weather stations

Essentially, in winter, the most frequent invasions of polar continental air from the north-eastern and eastern parts of Europe, as well as of arctic air-masses from the North, may determine severe cold waves over short periods of time, which may greatly be favorable to the accumulation and stagnation of cold air over the low-lying area of the Romanian Plain, thus producing stable thermal inversion conditions, greatly decreasing air-temperatures to very low values. In summer, under the influence of western oceanic and south-western tropical-maritime airmasses, undergoing a major process of adiabatic cooling while passing over the mountains, the weather is generally cloudless and warm, especially when eastern advections of hot and dry air get more intense. In case of such tropical continental advections, extremely high air-temperatures may occur, especially at the Bucharest-Filaret station, greatly influenced by the urbanization effect (Ionac, 2005). In this respect, it is noteworthy that air-temperatures recorded at BucharestFilaret weather station from 1900 to 2018, rank among the top ten high values in the country, as related to the: mean annual air-temperature $\left(13.4^{\circ} \mathrm{C}\right.$ in $2007-$ the third in the country, with the highest value reaching $13.6^{\circ} \mathrm{c}$ at DrobetaTurnuSeverin, in 2015); annual mean of minimum air-temperatures $\left(8.8^{\circ} \mathrm{C}\right.$ in 2015 - the fourth in the country, with the highest value reaching $10.8^{\circ} \mathrm{C}$ at Sulina, in 2007); annual mean of maximum air-temperatures $\left(19.7^{\circ} \mathrm{C}\right.$ in 2007 - the third in the country, with the highest value reaching $20.0^{\circ} \mathrm{C}$ at Giurgiu, in 2007) andthe annual absolute maximum air-temperature $\left(42.4^{\circ} \mathrm{C}\right.$ in 05.07 .2000 - the fifth in the country, with the highest absolute record of $43.5^{\circ} \mathrm{C}$ at Giurgiu, in 05.07 .2000 ) (ANM, 2018).

\section{AIR-TEMPERATURE DIFFERENCES AND SINGULARITIES IN BUCHAREST}

3.1. Mean annual air-temperatures are greatly varying between the two weather stations throughout the time period taken into consideration (1981- 
2010), with higher values at Bucharest-Filaret $\left(11.5^{\circ} \mathrm{C}\right)$ than Bucharest- Băneasa $\left(10.7^{\circ} \mathrm{C}\right)$, thus demonstrating the heat surplus inside the town area, as compared to its surrounding rural areas, mainly due to the additional input of the central, dense built-in spaces. The positive influence of urban spaces on air-temperatures is also demonstrated by the fact that the mean annual value recorded at Bucharest-Filaret equals to the highest equivalent value over Romania's entire territory $\left(11.5^{\circ} \mathrm{C}\right.$ at Mangalia), showing that specific physical geographical conditions, namely the artificial underlying active surface, covered by denselybuilt infrastructure, play a very important role in regulating the heat exchanges between land surface and atmosphere.

3.2. Mean monthly air-temperatures show a general increasing evolution from January, when minimum values have been recorded at both weather stations $\left(-1.4^{0} \mathrm{C}\right.$ at Bucharest-Băneasa and $-0.7^{\circ} \mathrm{C}$ at Bucharest-Filaret), to July, when the highest value is reached at Bucharest-Băneasa $\left(22.6^{\circ} \mathrm{C}\right)$, or August, at Bucharest-Băneasa $\left(22.6^{\circ} \mathrm{C}\right)$, as result of a more intense heating of the built-in

Tab. 1.Annual and monthly mean air-temperatures at the weather stations located

\begin{tabular}{|c|c|c|c|c|c|c|c|c|c|c|c|c|c|}
\hline $\begin{array}{c}\text { Weather } \\
\text { station }\end{array}$ & $\mathrm{J}$ & $\mathrm{F}$ & $\mathrm{M}$ & $\mathrm{A}$ & $\mathrm{M}$ & $\mathrm{J}$ & $\mathrm{J}$ & $\mathrm{A}$ & $\mathrm{S}$ & $\mathrm{O}$ & $\mathrm{N}$ & $\mathrm{D}$ & $\begin{array}{c}\text { Mean annual } \\
\text { air-temperature } \\
1981-2010\end{array}$ \\
\hline $\begin{array}{c}\text { Bucharest- } \\
\text { Băneasa }\end{array}$ & $\mathbf{- 1 . 4}$ & 0.2 & 5.1 & 11.0 & 16.8 & 20.7 & $\mathbf{2 2 . 6}$ & 21.8 & 16.9 & 10.5 & 4.5 & -0.2 & $\mathbf{1 0 . 7}$ \\
\hline $\begin{array}{c}\text { Bucharest- } \\
\text { Filaret }\end{array}$ & $\mathbf{- 0 . 7}$ & 1.1 & 6.1 & 11.9 & 17.6 & 21.4 & 23.4 & $\mathbf{2 4 . 1}$ & 17.7 & 11.8 & 5.5 & -1.4 & $\mathbf{1 1 . 5}$ \\
\hline
\end{tabular}

town areas, occurring especially under conditions of atmospheric stability, when cloudiness and air-humidity maintain relatively low values. Then, airtemperatures slowly decrease to negative values $\left(-1.4^{0} \mathrm{C}\right)$ until December, at Bucharest-Filaret, or January, at Bucharest- Băneasa, demonstrating that the artificial land cover inside the city not only that gets heated easier and faster than the vegetated green spaces in its surroundings, but it also delays the occurrence of both lowest and highest values by one month. All throughout the year, the mean monthly air-temperature values recorded at Bucharest-Filaret weather station keep constantly higher than those recorded at Bucharest- Băneasa (from $0.7^{\circ} \mathrm{C}$ in June to $2.3^{\circ} \mathrm{C}$ in August), except for December, when intra-urban airtemperature keeps lower than the extra-urban one, as direct result of massive radiative cooling over extensive active-surface layers. Essentially though, the town's thermal superiority is evident all the year round but the greatest airtemperature differences occur mainly during the months with stable atmospheric 
conditions, when they get more prominent, either positively $\left(+2.3^{0} \mathrm{C}\right.$ in August $)$ or negatively $\left(-1.2^{\circ} \mathrm{C}\right.$ in December) (Table 1$)$.

3.3. The monthly means of hourly air-temperature values at four observation hours (01.00, 07.00, 13.00, 19.00 local time) are more expressive of the thermal differences between the central and peripheral town's areas (Table 2):

- at 1.00 o'clock, the greatest air-temperature differences occur in summer (July), as result of the overnight intense radiative cooling of buildings in central and residential areas. The lowest air-temperature values are delayed by one month between the two weather stations, just as the daily values, thus reflecting that radiative cooling processes play an important part in thermal differentiation of the two main landcover types: the built-in and the open-spaced surfaces;

- at 7.00 o'clock, the thermal differences between the two weather stations get lower, except for November - February time period, when air-temperatures at Bucharest-Filaret keep much higher than at Bucharest-Băneasa, mainly as result of the additional heat input inside the city, where domestic heating systems work at full capacity;

- at 13.00 o'clock, the hourly air-temperature values in December, at Bucharest-Filaret keep lower than those in the peripheral rural areas, recorded at Bucharest-Băneasa station, mainly because of the more intense radiative cooling of the artificial surfaces, on one hand, and of the higher frequency of low stratiformis clouds becoming persistent under conditions of thermal inversions;

- at 19.00 o'clock, both the highest and the lowest air-temperature values are no longer synchronous between the two weather stations, as they are delayed by one month from the extra-urban to the intra-urban station, either as effect of a more stable atmosphere in August, favoring excessive heating of the central built-in areas as compared to the peripheral vegetated ones, or as a consequence of the more intense radiative cooling processes occurring over the artificial active surfaces in December, which must intensely be heated by artificial heating systems.

As regards the annual variation of air-temperature values recorded at the four hours of observation $(1.00,7.00,13.00,19.00)$, some other interesting aspects are still to be noted: for instance, the air-temperature values at night are consistently higher at Bucharest-Filaret than at Bucharest-Băneasa, in all months, except for December, when air-temperature values inside the city get lower than in the outskirts, due to the more intense radiative cooling processes of all surrounding horizontal and vertical surfaces. Moreover, the thermal differences between the two weather stations seem to keep very low but they get higher during summertime (July-August), when the infra-red emissions of all surrounding artificial surrounding surfaces increase. In the morning (at 7.00 
o'clock), as the radiation budget values get more homogenized, while turning from the outgoing to the incoming radiation transfers, the air-temperatures recorded at the two weather stations are very similar, except for a small positive deviation occuring at Bucharest-Filaret, in summer. At noon (13.00 o'clock), the same rule applies for both weather stations, but air-temperature values start increasing towards winter months, when the additional heating input of the city becomes evident. In the evening (19.00 o'clock), the central built-in areas have constantly higher air-temperature values than the open-air spaces in the outskirts, but in August, the thermal difference between the two weather stations reaches its highest value, probably due to the heavy traffic during towards evening rush hours, when all working people come back home for rest, or to the more intense heat losses of all built-in surfaces inside the city.

Tab. 2.Monthly means of hourly air-temperature values at the four hours of observation, at the two weather stations in Bucharest town area, 1981-2010

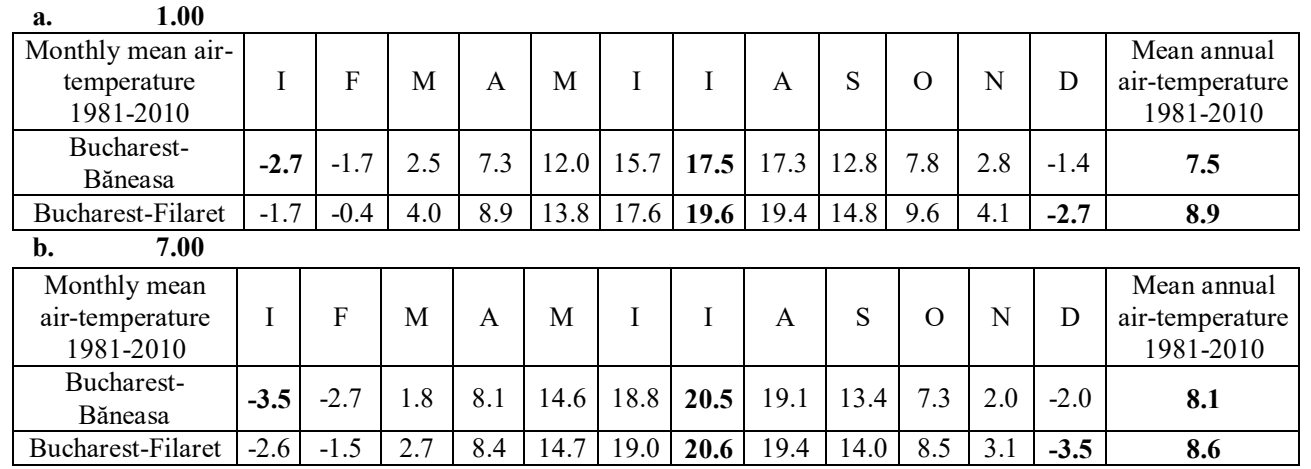

\begin{tabular}{|c|c|c|c|c|c|c|c|c|c|c|c|c|c|}
\hline 13.00 & & & & & & & & & & & & & \\
\hline $\begin{array}{c}\text { Monthly mean air- } \\
\text { temperature } \\
1981-2010 \\
\end{array}$ & I & $\mathrm{F}$ & M & A & M & I & I & A & $\mathrm{S}$ & $\mathrm{O}$ & $\mathrm{N}$ & D & $\begin{array}{c}\text { Mean annual } \\
\text { air-temperature } \\
1981-2010 \\
\end{array}$ \\
\hline Bucharest-Băneasa & 1.6 & 4.2 & 9.7 & 16.2 & 22.2 & 25.8 & 28.0 & 28.0 & 23.0 & 16.5 & 8.6 & 2.6 & 15.5 \\
\hline Bucharest-Filaret & 1.7 & 4.5 & 10.2 & 16.8 & 22.8 & 26.2 & 28.4 & 28.7 & 23.6 & 17.1 & 8.9 & 1.6 & 15.9 \\
\hline 19.00 & & & & & & & & & & & & & \\
\hline $\begin{array}{c}\text { Monthly mean air- } \\
\text { temperature } \\
1981-2010\end{array}$ & I & $\mathrm{F}$ & M & A & M & I & I & $\mathrm{A}$ & $\mathrm{S}$ & $\mathrm{O}$ & $\mathrm{N}$ & $\mathrm{D}$ & $\begin{array}{c}\text { Mean annual } \\
\text { air-temperature } \\
1981-2010 \\
\end{array}$ \\
\hline $\begin{array}{c}\text { Bucharest- } \\
\text { Băneasa }\end{array}$ & -1.1 & 0.8 & 6.5 & 12.6 & 18.2 & 22.3 & 24.4 & 22.9 & 18.4 & 10.3 & 4.5 & -0.2 & 11.6 \\
\hline Bucharest-Filaret & -0.3 & 1.9 & 7.5 & 13.5 & 19.1 & 22.8 & 24.8 & 28.7 & 18.5 & 12.1 & 5.8 & -1.1 & 12.8 \\
\hline
\end{tabular}

3.4. The double daily and annual variation of air-temperature values, represented by the corresponding thermo-isopleths, gives the most expressive image on the evolution of air-temperature values over any specific moment of 
the day and year. In fact, three-dimensional isopleths provide an accurate image on the state and distribution of air-temperature field, which rise up at noon hours and sink in the morning or in the evening hours. The most prominent positive uprisings of the air-temperature field obviously occur around noon, in summer, but a certain thermal inertia becomes more evident both in the annual distribution of air-temperature values, which concentrate mostly towards the negative values in January and February, that is one or two months later than the winter solstice time, and in their daily distribution as well, when higher air-temperature values persist until later in the after-noon.

Generally, although pretty similar, the thermo-isopleths reconstructed for the two weather stations located in Bucharest town-area also reflect some particular aspects for each one of it. Consequently, in the case of BucharestBăneasa weather station (Fig. 3 left), the period of maximum heating (over $25^{\circ} \mathrm{C}$ ) sets in rather abruptly around noon (12.00 hrs.), reaches a peak value at 13.00 $\mathrm{hrs}$. and then, gradually decreases in the after-noon hours $(14.00-16.00)$, to minimum values in the evening $(20.00 \mathrm{hrs}$.). A slight migration of the entire thermal field towards right also becomes obvious, mainly because the thermal relief fiorms during winter are largely attenuated as direct result of a higher thermal inertia that open-space, vegetated areas have in comparison with the built-in ones, as they get heated more slowly during spring, either because they keep open to the free circulation of air for a longer period of time, or because a large proportion of the air heat is consumed to thaw/melt down the snow cover occuring during winter time.

In case of the Bucharest-Filaret weather station (Fig. 3 right), the thermal superiority towards Bucharest-Băneasa is evident; all air-temperature values in the corresponding days and months of the time-period taken into consideration, keeping obviously higher than those at the extra-urban station, mainly due to the heat excess inside the built-in areas, where the walls of the buildings, the asphalted streets and boulevards, the industrial and commercial spaces etc. largely emit heat towards the surrounding environment. Unlike the BucharestBăneasa station, the period of most intense heating occurs one hour later though (at $13.00 \mathrm{hrs}$.) and is better centered on the summer months, as the thermal field forms are somehow more symmetrically distributed around the summer solstice month (June), but they persist longer towards the evening hours, because of the slow outgoing radiative processes or the intre-urban areas. On the contrary, the cooling period during winter, especially in January and February, looks more attenuated than its counterpart at Bucharest-Filaret weather station; the intraurban air-temperatutres obviously keeping much higher than in the peripheral surrounding areas. This is evidently the direct effect of artificial heating systems that increase the heat input inside the city spaces. Moreover, the isopleth lines 
getting closer to one another around noon hours, at Bucharest-Băneasa weather station, in the transition seasons, is indicative of a larger air-temperature daily and annual variation, because the more extensive open-air spaces covered by vegetation become dominant in the outskirts areas, allowing more intense heat exchanges between the ground surface and the open atmosphere.
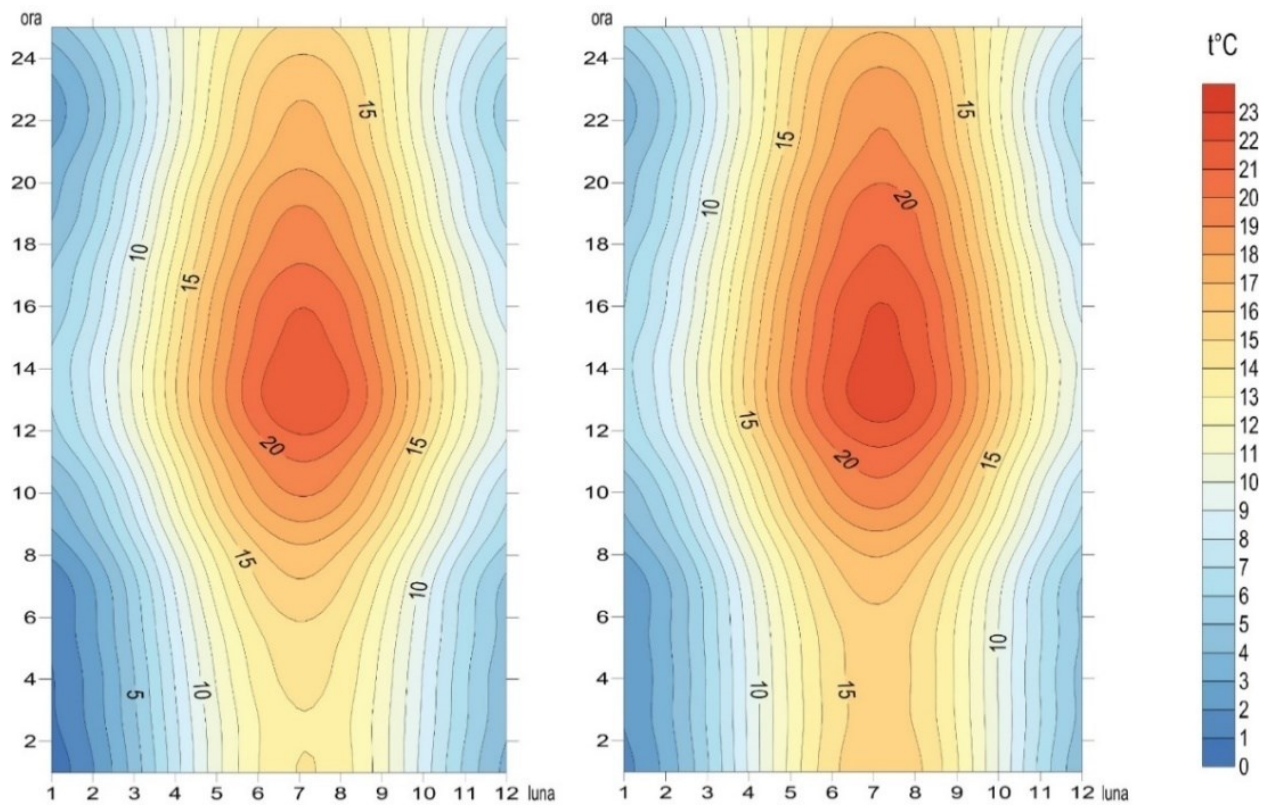

Fig.0. Comparative isotherms for Bucharest-Băneasa (left) and Bucharest-Filaret (right) weather stations

3.5. The means of annual and monthly maximum and minimum airtemperature values display totally different variation patterns than the mean values but generally provide a very good outlook on their extreme variation limits between the two basic types of urban environments.

In this respect, the mean of the annual and monthly maximum airtemperature values, broadly represented by thehighest air-temperatures from all the four hourly values recorded each day, during the 1981-2010 interval, highlights the continental climate influences mainly affecting the urban territory in summer, when frequent advections of tropical-dry air from the

South and the West determine the rapid and abrupt increase of thermal differences between the central and peripheral urban areas, from only about $0.1^{\circ} \mathrm{C}$ in January, to more than $0.8^{\circ} \mathrm{C}$ in August (Table 3). However, the mean 
annual difference of daily maximum air-temperature values between the two weather stations keeps pretty low $\left(0.3^{0} \mathrm{C}\right)$, showing that, in fact, the UHI effect is spatially and temporally restricted to local favorable conditions. On the contrary, the differences between the highest and the lowest daily maximum airtemperature values get much greater at each weather station, reaching up to $0.7^{\circ} \mathrm{C}$; for example, at Bucharest-Băneasa, the difference between the airtemperature values recorded in July or August $\left(28,1^{\circ} \mathrm{C}\right)$ and January $\left(1,8^{\circ} \mathrm{C}\right)$ is $26.3^{\circ} \mathrm{C}$, while the corresponding annual air-temperature amplitude at BucharestFilaret is greater $\left(27.1^{\circ} \mathrm{C}\right)$, deriving from the temperature difference between July $\left(28.9^{\circ} \mathrm{C}\right)$ and December $\left(1,8^{\circ} \mathrm{C}\right)$.

Tab. 3.Annual and monthly means of maximum air-temperature values in Bucharest town-area, 1981-2010

\begin{tabular}{|c|c|c|c|c|c|c|c|c|c|c|c|c|c|}
\hline $\begin{array}{c}\text { Weather } \\
\text { station }\end{array}$ & J & F & M & A & M & J & J & A & S & O & N & D & $\begin{array}{c}\text { Annual mean of } \\
\text { maximum air- } \\
\text { temperature values } \\
\text { 1981-2010 }\end{array}$ \\
\hline $\begin{array}{c}\text { Bucharest- } \\
\text { Băneasa }\end{array}$ & $\mathbf{1 . 8}$ & 4.3 & 9.8 & 16.3 & 22.3 & 25.9 & $\mathbf{2 8 . 1}$ & $\mathbf{2 8 . 1}$ & 23.0 & 16.6 & 8.8 & 2.9 & $\mathbf{1 5 . 7}$ \\
\hline $\begin{array}{c}\text { Bucharest- } \\
\text { Filaret }\end{array}$ & 1.9 & 4.7 & 10.4 & 16.9 & 22.9 & 26.3 & 28.5 & $\mathbf{2 8 . 9}$ & 23.7 & 17.2 & 9.1 & $\mathbf{1 . 8}$ & $\mathbf{1 6 . 0}$ \\
\hline
\end{tabular}

As for the mean of the annual and monthly minimum air-temperature values, their variation from one month to another is larger at both weather stations than their maximum counterpart values (Tab. 4). For example, the annual difference of daily minimum air-temperature values between the two weather stations is $1.5^{\circ} \mathrm{C}$ (that is the difference between $8.1^{\circ} \mathrm{C}$ at Bucharest-Filaret and $6.6^{\circ} \mathrm{C}$ at Bucharest-Băneasa), revealing that the intra-urban spaces remain constantly warmer than the peripheral ones, exposed to free air-circulation, partly because minimum air-temperature values increase significantly in summer, when the radiation budget is positive, and because extra heating sources add to the natural ones in winter, accordingly increasing the heat surplus inside the city area. These are the main reasons why in July, for example, the difference of the daily minimum air-temperature values between the two weather stations gets as high as $4.0^{\circ} \mathrm{C}\left(21.3^{\circ} \mathrm{C}\right.$ at Bucharest-Filaret and $17.3^{\circ} \mathrm{C}$ at Bucharest-Băneasa, respectively), while in winter, the corresponding values are the same at both weather stations ($4.1{ }^{\circ} \mathrm{C}$ ) but are delayed by one month from Bucharest-Filaret (with a minimum value in December) to Bucharest- Băneasa (with a minimum values in January). Moreover, it is also important to note that the differences between the mean values of minimum air-temperatures are noticeably higher than the mean values of maximum air-temperatures, indicating that the effect of artificial heating over the 
underlying surfaces inside the city is more prominent in increasing the thermal minimum values than in increasing the maximum ones. As for the difference between the highest $\left(17.3^{\circ} \mathrm{C}\right.$ at Bucharest-Băneasa and $21.3^{\circ} \mathrm{C}$ at Bucharest-Filaret) and the lowest values $\left(-4.1^{\circ} \mathrm{C}\right.$ at both weather stations) of minimum airtemperature means, actually representing the annual amplitude of the minimum air-temperature means, it keeps much hgher at Bucharest-Filaret $\left(25.4^{\circ} \mathrm{C}\right)$ than at Bucharest-Băneasa $\left(21 \cdot 4^{0} \mathrm{C}\right)$.

Tab. 4.Annual and monthly means of maximum air-temperature values in Bucharest town-area, 1981-2010

\begin{tabular}{|c|c|c|c|c|c|c|c|c|c|c|c|c|c|}
\hline $\begin{array}{c}\text { Weather } \\
\text { station }\end{array}$ & $\mathrm{J}$ & $\mathrm{F}$ & $\mathrm{M}$ & $\mathrm{A}$ & $\mathrm{M}$ & $\mathrm{J}$ & $\mathrm{J}$ & $\mathrm{A}$ & $\mathrm{S}$ & $\mathrm{O}$ & $\mathrm{N}$ & $\mathrm{D}$ & $\begin{array}{c}\text { Annual mean of } \\
\text { minimum air- } \\
\text { temperature } \\
\text { values 1981-2010 }\end{array}$ \\
\hline $\begin{array}{c}\text { Bucharest- } \\
\text { Băneasa }\end{array}$ & - & $\mathbf{4 . 1}$ & -3.2 & 1.2 & 6.7 & 11.7 & 15.5 & $\mathbf{1 7 . 3}$ & 17.0 & 12.2 & 6.6 & 1.4 & - \\
\hline $\begin{array}{c}\text { Bucharest- } \\
\text { Filaret }\end{array}$ & - & -1.0 & 2.5 & 8.0 & 13.4 & 17.2 & $\mathbf{2 1 . 3}$ & 19.3 & 13.7 & 8.2 & 2.7 & $\mathbf{6 . 1}$ & $\mathbf{6 . 6}$ \\
\hline
\end{tabular}

\subsection{Extreme air-temperatures}

Represented by either the absolute highest (absolute maximum) or lowest (absolute minimum) air-temperatures that have ever been recorded in the location of reference, over the entire period of interest, the extreme airtemperatures are mainly resulting from the combined influence of radiative and dynamic factors, producing episodes of severe weather, characterized by either excessive heating, or cooling, respectively. For each weather station, a single extreme air-temperature value (maximum or minimum) can therefore be recorded at every hour, day, month and year of observations; such extreme values representing important indicators of the climatic profile of the region under study.

The annual and monthly maximum air-temperatures / Absolute maximum air-temperatures are mainly occurring when anticyclonic ridges from eastern Europe or northern Africa extend over Romania's territory, thus allowing the advection of tropical-dry air from the South or the South-East, on one hand, or because of the excessive heating of the built-in areas in the central parts of Bucharest city, provided that air humidity and cloudiness are very low, on the other hand.

The annual and monthly variation of the maximum air-temperature values at the two weather stations located in the area of Bucharest municipality clearly reveal once again the thermal superiority of the central built-in spaces over the 
vegetated peripheral ones, as all absolute maximum air-temperature values recorded at Bucharest-Filaret weather station are evidently higher than those recorded at Bucharest-Băneasa, in all months of the year, irrespective when they occurred. The maximum air-temperature differences between the two weather stations of reference vary from $0,3^{\circ} \mathrm{C}$ (in April) to $2,0^{\circ} \mathrm{C}$ (in January) (Tab. 5). The absolute maximum air-temperature values reached as high as $41,0^{\circ} \mathrm{C}$ at Bucharest-Băneasa (on 5 July 2000) and $41,7^{\circ} \mathrm{C}$ at Bucharest-Filaret (on the same day), demonstrating that, in this context, it was the synoptic pattern that produced these record values, supported by excessive heating and radiating processes of the artificial ground surfaces inside the city areas. However, the difference between the highest and the lowest maximum air-temperature values recorded at each weather station, that is: $26,4^{\circ} \mathrm{C}$ at Bucharest-Băneasa $\left(41,0^{\circ} \mathrm{C}\right.$ in July minus $14,6^{\circ} \mathrm{C}$ in January) and $25,2^{\circ} \mathrm{C}$ at Bucharest-Filaret $\left(41,7^{\circ} \mathrm{C}\right.$ in July minus $16,5^{\circ} \mathrm{C}$ in December), clearly expresses the significant heat input inside the city areas, especially in winter, which leads to a consistent attenuation of annual absolute thermal amplitudes in comparison with the open-space surrounding areas.

Tab. 5. Annual and monthly absolute maximum air-temperature values in Bucharest town area, 1981-2010

\begin{tabular}{|c|c|c|c|c|c|c|c|c|c|c|c|c|}
\hline Weather station & $\mathrm{J}$ & $\mathrm{F}$ & $\mathrm{M}$ & $\mathrm{A}$ & $\mathrm{M}$ & $\mathrm{J}$ & $\mathrm{J}$ & $\mathrm{A}$ & $\mathrm{S}$ & $\mathrm{O}$ & $\mathrm{N}$ & $\mathrm{D}$ \\
\hline Bucharest- Băneasa & $\mathbf{1 4 . 6}$ & 22.0 & 25.0 & 30.2 & 33.3 & 37.6 & $\mathbf{4 1 . 0}$ & 38.0 & 35.0 & 32.0 & 25.0 & 17.8 \\
\hline \multirow{2}{*}{ Day / Year of occurence } & 22, & 27, & 26, & 6, & 3, & 26 & 5, & 5, & 15, & 6, & 10, & 18, \\
& 2007 & 1995 & 1994 & 1998 & 2003 & 2007 & 2000 & 1998 & 1987 & 1984 & 2010 & 1989 \\
\hline Bucharest- Filaret & 16.6 & 22.2 & 25.6 & 30.5 & 34.3 & 38.2 & $\mathbf{4 1 . 7}$ & 37.7 & 35.4 & 32.6 & 25.9 & $\mathbf{1 6 . 5}$ \\
\hline \multirow{2}{*}{ Day / Year of occurence } & $29 ;$ & $27 ;$ & $26 ;$ & $6 ;$ & $3 ;$ & $26 ;$ & $5 ;$ & $24 ;$ & $17 ;$ & $6 ;$ & $10 ;$ & $29 ;$ \\
& 2002 & 1995 & 2001 & 1998 & 2003 & 2007 & 2000 & 2007 & 1986 & 1984 & 2010 & 2002 \\
\hline
\end{tabular}

The annual and monthly minimum air-temperatures / Absolute minimum air-temperatures may usually occur in the region of analysis only if certain dynamic and physical geographic factors combine their influence, so that a favourable synoptic pattern for excessive cooling could be produced. The main processes that may accordingly determine significant air-temperature decrease, especially in winter, generally refer to the following conditions:

- Advections of cold arctic or polar air along the eastern peripheries of Scandinavian or eastern European anticyclones, correlated with the formation, over the Aegean or the Mediterranean Seas, of powerful low-pressure areas, altogether determining the occurrence of strong blizzards, accompanied by heavy snowfalls;

- Nocturnal radiative cooling processes, which get intensified on 


\section{Ionac Nicoleta, Urițescu Bogdan, Grigore Elena, Constantin Dana Maria, Dumitrescu A.}

conditions of a high-pressure field maintaining a stable atmosphere, with cloudless skies and persistent cold and dry air, that may accumulate and stagnate in the low-lying areas of the Romanian Plain, thus creating extreme airtemperature inversions. Moreover, a longer persistence of snow cover may also intensify the radiative cooling processes of the land surfaces which, on conditions of calm weather, get very intense, especially in winter, thus significantly reducing the turbulent exchange quotients of the air and preventing their heating, by seriously reducing convection mechanisms;

- In urban areas, the inter-twinned radiations among the walls and the paved streets or concrete surfaces of the town play an important role in the excessive cooling of built-in areas, especially in winter.

Due to the above-mentioned causes, the annual and monthly minimum airtemperatures recorded at the two weather stations in Bucharest town area (Table 6), over the 1981-2010 period, clearly show that most of the time, the in-town areas constantly keep higher than the cooresponding values in the outskirts regions, except for January, when the intense radiative cooling losses inside the city become more prominent. Under these conditions, at Bucharest- Băneasa weather station, the highest minimum air-temperature value was $8.4^{\circ} \mathrm{C}$ in $15 \mathrm{July}$ 1993 and the lowest one was $-25.2^{\circ} \mathrm{C}$ in 26 December 2002, while at BucharestFilaret, the highest minimum air-temperature value was $10.4^{\circ} \mathrm{C}$ in 10 July 1998 and the lowest one was $-23.8^{\circ} \mathrm{C}$ in 26 December 2010 , meaning that the airtemperature difference between the two extreme values reaches $33.6^{\circ} \mathrm{C}$ at Bucharest- Băneasa and $34.2^{\circ} \mathrm{C}$ at Bucharest-Filaret. To conclude, this means

Tab. 6. Annual and monthly absolute minimum air-temperature values in Bucharest town area, 1981-2010

\begin{tabular}{|c|c|c|c|c|c|c|c|c|c|c|c|c|}
\hline Weather station & $\mathrm{J}$ & $\mathrm{F}$ & $\mathrm{M}$ & $\mathrm{A}$ & $\mathrm{M}$ & $\mathrm{J}$ & $\mathrm{J}$ & $\mathrm{A}$ & $\mathrm{S}$ & $\mathrm{O}$ & $\mathrm{N}$ & $\mathrm{D}$ \\
\hline Bucharest- Băneasa & -21.4 & -23.7 & -18.2 & -3.8 & 0.8 & 6.2 & $\mathbf{8 . 4}$ & 7.6 & 2.2 & -7.0 & -19.0 & $\mathbf{- 2 5 . 2}$ \\
\hline Day / Year of occurence & 13,$1985 ;$ & 14, & 2, & 4, & 3, & 3, & 15, & 29 & \multirow{2}{*}{} & 30, & 26, & 26,2002 \\
& 31,1987 & 1985 & 2005 & 2004 & 2007 & 2008 & 1993 & 1981 & 1,2 & 1997 & 1993 & 26,2 \\
\hline Bucharest- Filaret & -22.0 & -18.6 & -12.4 & -1.5 & 4.7 & 9.6 & $\mathbf{1 0 . 4}$ & 9.6 & 5.5 & -4.3 & -11.8 & $\mathbf{- 2 3 . 8}$ \\
\hline & & $14 ;$ & 4,$6 ;$ & $7 ;$ & $6 ;$ & $1 ;$ & $10 ;$ & $29 ;$ & $27 ;$ & $30 ;$ & $26 ;$ & $26 ;$ \\
\hline Day / Year of occurence & $13 ; 1985$ & 1985 & 1987 & 2003 & 1999 & 1997 & 1998 & 1981 & 1992 & 1997 & 1993 & 2010 \\
\hline
\end{tabular}

that although the thermal minimum values inside de city are generally higher than those recorded in extra-urban environments, the annual difference between them keeps higher due to many local influences determining large variations on small spaces. 


\section{Conclusions}

The impact of the urban underlying surface on the time range and distribution of air-temperatures in Bucharest town area has been assessed on basis of comparative values recorded at two different (intra- and extra-urban) meteorological stations (Bucharest-Filaret and Bucharest-Băneasa respectively), revealing the thermal superiority of in-town spaces; all air-temperature values in the corresponding days and months of the time-period taken into consideration, keeping obviously higher at Bucharest-Filaret than those at the extra-urban station (Bucharest- Băneasa), mainly due to the heat excess inside the built-in areas.

\section{References}

1. Bian Tao, GuoyuRen\&Bingxiang Zhang \&Lei Zhang \&YanxiaYue (2014) Urbanization effect on long-term trends of extreme temperatureindices at Shijiazhuang station, North China, TheorApplClimatol, DOI 10.1007/s00704-0141127-x

2. Chen, A., et al. (2014) Effect of urban green patterns on surface urban cool islands and its seasonal variations, Urban Forestry\&Urban Greening, http://dx.doi.org/10.1016/j.ufug.2014.07.006.

3. Cheval S., Dumitrescu Al. (2018) The summer surface urban heat island of Bucharest (Romania) retrieved from MODIS images, Theor. Appl. Climatol, DOI 10.1007/s00704-014-1250-8.

4. Gaffin S R, Rosenzweig C, Khanbilvardi R, et al. (2008) Variations in New York city's urban heat island strength over time and space. TheorApplClimatol, 94: 1-11. https://doi.org/10.1007/s00704-007-0368-3

5. Ionac Nicoleta (2005) Main Bioclimatic Characteristics of the Bucharest Urban Area, Annals of the University of Bucharest, Geography series, Anno LI/2002, Bucharest, p. 33-43, ISSN 1013-4115.

6. Li J., Song C., Cao L., Zhu F., Meng X., Wu J. (2011) Impacts of landscape structure on surface urban heat islands: a case study of Shanghai, China, Remote Sens. Environ. 115 (12), 3249-3263. https://doi.org/10.1016/j.rse.2011.07.008

7. Matzarakis A., Rutz F., Mayer H. (2010) Modelling radiation fluxes in simple and complex environments: basics of the RayMan model, Int. J. Biometeorol., 54 (2) 131-139. DOI 10.1007/s00484-009-0261-0

8. National Administration of Meteorology (2018) 100 Climatic Records in Romania, Bucharest.

9. Sun R., Chen L. (2012) How can urban water bodies be designed for climate adaptation?, Landsc. Urban Plan., $105 \quad$ (1-2), 27-33. https://doi.org/10.1016/j.landurbplan.2011.11.018

10. Voogt J. A., Oke T.R. (2003) Thermal remote sensing of urban climates, Remote Sens. Environ., 86 (3), 370-384. https://doi.org/10.1016/S0034-4257(03)00079-8 
11. Wang J., Yan Z. W., Li Z. et al. (2013) Impact of urbanization on changes in temperature extremes in Beijing during 1978-2008. Chin Sci Bull, 2013, 58: $4679 \square 4686$, doi: 10.1007/s11434-013-5976-y.

12. Weng Q. (2009) Thermal infrared remote sensing for urban climate and environmental studies: methods, applications and trends, ISPRJ, Photogramm. Remote Sens., 64 (4), 335-344. https://doi.org/10.1016/j.isprsjprs.2009.03.007

13. Zhou W., Huang G., Cadenasso M. L. (2011) Does spatial configuration matter? Understanding the effects of land cover pattern on land surface temperature in urban landscapes, Landsc. Urban Plan., $102 \quad$ (1), 54-63. https://doi.org/10.1016/j.landurbplan.2011.03.009

(C) 2020 by the authors. Licensee UAIC, Iasi, Romania. This article is an open access article distributed under the terms and conditions of the Creative Commons Attribution (CC BY-NC-ND) license (https:// creativecommons.org/licenses/by-nc-nd/4.0). 